\title{
Perancangan dan Pembuatan Indikator Volume Kernel di Kernel Storage Bin pada Stasiun Nut and Kernel Pabrik Kelapa Sawit
}

\author{
Idad Syaeful Haq ${ }^{1,1 *}$, Deni Rachmat ${ }^{1}$, Ari Pratama ${ }^{1}$ \\ ${ }^{1}$ Teknologi Pengolahan Sawit, Fakultas Vokasi, Institut Teknologi Sains Bandung, Indonesia
}

\begin{abstract}
Abstrak. Kernel Storage Bin (KSB) merupakan tangki penyimpan sementara kernel produksi di Stasiun Nut and Kernel yang terletak di atas. Proses pengiriman kernel produksi menuju KSB menggunakan konveyor Dry Kernel Distributing dan konveyor Cross Dry Kernel. Persoalan yang sering terjadi pada bagian ini adalah KSB mengalami penuh dan terjadinya penumpukan kernel pada konveyor. Salah satu solusi untuk mencegah persoalan tersebut, adalah dengan menambahkan alat indikator di KSB. Harapan adanya alat indikator ini dapat mencegah terjadinya kerusakan konveyor, serta memudahkan operator mengontrol pengisian kernel di KSB. Metode penelitian menggunakan observasi langsung dalam mengidentifikasi penyebab masalah dengan metode Root Cause Analysis (RCA) dengan alat bantu Diagram Ishikawa guna memperoleh akar persoalan beserta solusi yang diberikan. Alat indikator dibuat menggunakan sensorlimit switch yang terhubung dengan bandul level dan panel indikator. Alat ini mampu bekerja baik dengan penanda visual dalam bentuk lampu indikator, serta penanda audio dalam bentuk suara sirine. Lampu indikator berwarna hijau akan menyala ketika tumpukan kernel di KSB masih dalam kondisi rendah (low), dan lampu indikator akan berwarna merah, serta sirine menyala ketika tumpukan kernel di KSB penuh (high). Taksiran total jumlah berat rata-rata kernel yang tertampung pada KSB-1 saat kondisi penuh adalah 85,50 ton, sedangkan pada KSB-2 adalah 90,89 ton dan KSB-3 adalah 62,75 ton. Pengujian putaran reverse otomatis motor listrik pada konveyor Dry Kernel Distributing saat KSB nomor-1, 2 dan 3 kondisi penuh memberikan hasil kinerja yang baik. Pemasangan alat indikator (berbasis visual dan audio) memberikan hasil kernel tidak mengalami penumpukan lagi di KSB. Kernel yang tidak menumpuk akan mengurangi kerusakan konveyor Cross Dry Kernel, serta memudahkan operator mengontrol penyimpanan kernel produksi.
\end{abstract}

Kata Kunci : Kernel Storage Bin, Alat Indikator, Konveyor Cross Dry Kernel

\footnotetext{
1* Corresponding author: idadshaq@yahoo.co.id
} 
Research Paper Vol 3, No 2, Tahun 2021

\section{Pendahuluan}

Proses pengolahan Tandan Buah Segar (TBS) di Pabrik Kelapa Sawit (PKS) terdapat beberapa rangkaian pengolahan untuk menghasilkan produk berupa Crude Palm Oil (CPO) dan Palm Kernel (PK). Stasiun Nut and Kernel merupakan salah satu stasiun pengolahan yang ada di PKS. Press cake hasil luaran Stasiun Press diolah pada stasiun Nut and Kernel dan dipisahkan menjadi produk berupa sabut (fiber), cangkang dan kernel. Produk kernel ini didistribusikan menuju Kernel Storage Bin (KSB) yang berfungsi sebagai tempat penyimpanan sementara sebelum dilakukan pengiriman (despatch kernel).

Pendistribusian dan pembagian umpan kernel menuju KSB dilakukan oleh konveyor Cross Dry Kernel jenis ulir (screw conveyor). Pengaturan pengumpanan kernel ke KSB diatur secara manual, dan seringkali penyimpanan kernel di KSB mengalami penuh dan menumpuk pada bagian tengah. Penumpukan kernel menyebabkan chute conveyor tertutupi. Akibat chute conveyor tertutupi terjadi penumpukan kernel di konveyor, sehingga dapat menyebabkan kerusakan screw conveyor, selain itu kernel berisiko tumpah ke lantai bawah KSB.

\section{Landasan Teori}

\subsection{Analisis Akar Masalah (Root Cause Analysis/RCA)}

RCA adalah metode yang digunakan untuk menemukan akar masalah atau suatu ketidaksesuaian dari persoalan. RCA mampu mengkoreksi dan mengeliminasi penyebab dan mencegah persoalan tersebut berulang kembali. RCA merupakan pendekatan sistematis untuk memperoleh akar penyebab dari proses persoalan yang ditemui. Di dalam metode RCA ini terdapat berbagai alat bantu (tool) di antaranya adalah 5 Why, Diagram Ishikawa/Fishbone dan lainnya. Diagram Ishikawa merupakan diagram berbentuk tulang ikan yang akan membantu menemukan berbagai penyebab (causes) dan variasi kemungkinannya (possibilities).

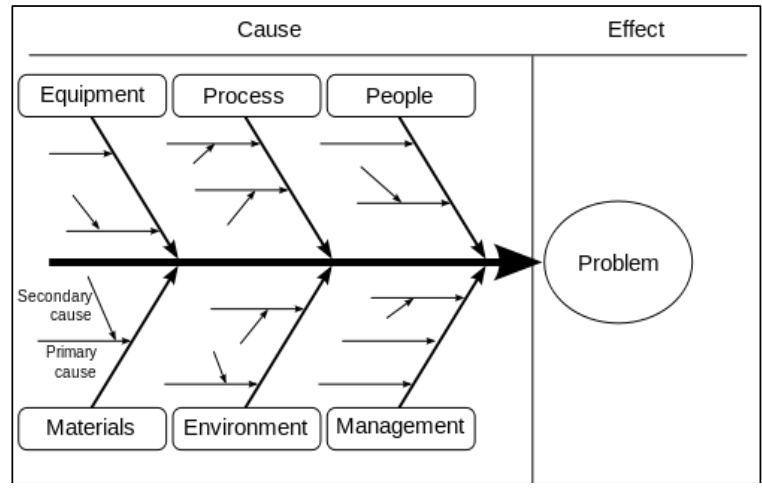

Gambar 1. Diagram Ishikawa[6]

Umumnya Diagram Ishikawa digunakan untuk desain produk, kontrol kualitas dan identifikasi faktor-faktor potensial yang menyebabkan efek keseluruhan. Setiap penyebab atau alasan ketidaksempurnaan merupakan sumber dari permasalahan. Penyebab umumnya dikelompokkan ke dalam kategori utama untuk mengidentifikasi sumbersumber masalahnya. Kategori ini meliputi: (1)Manusia (siapa saja yang terlibat dalam proses); (2)Metode (bagaimana proses yang dilakukan dan persyaratan khususnya), (3)Mesin (peralatan, komputer, peralatan dan lain-lain yang diperlukan untuk menyelesaikan pekerjaan), (4)Material (bahan baku, suku cadang yang digunakan untuk menghasilkan produk akhir), (5)Pengukuran (data yang dihasilkan dari proses yang digunakan untuk mengevaluasi kualitas), (6)Lingkungan (kondisi, seperti lokasi, waktu, suhu operasi).

Diagram sebab-akibat (cause-effect) dapat mengungkapkan hubungan penting dalam sebuah variabel dan kemungkinan penyebab yang memberikan informasi tambahan ke dalam perilaku proses. Penyebab ini dapat diturunkan dari proses curah pendapat (brainstorming) yang dimasukan dalam label kategori tulang ikan tersebut. Teknik untuk membuatnya dengan pertanyaan "mengapa" (why). Kategori dalam diagram sebab-akibat pada manufaktur biasanya mencakup $4 \mathrm{M}$, yaitu Mesin/teknologi, Metode (proses/inspeksi), Material dan Manusia[6].

\subsection{Stasiun Nut and Kernel dan Kernel Storage Bin (KSB)}

Stasiun nut and kernel merupakan salah satu stasiun pengolahan yang ada di PKS. Stasiun Nut and Kernel mengolah press cake 


\section{JVTI}

Research Paper Vol 3, No 2, Tahun 2021

hasil dari proses pengepressan di Stasiun Pressing. Press cake ini akan dipisahkan antara nut dan sabut (fibre) yang masih menempel kemudian nut akan dipecah hingga menghasilkan kernel. Kernel produksi hasil pemisahan akan ditampung sementara pada Kernel Silo Drier untuk mengurangi kadar air yang terkandung di dalamnya sesuai paramater produksi. Selanjutnya kernel produksi ini disimpan di KSB dengan paramater standar, yaitu prosentase moisture sebesar 6-7\%, prosentase kekotoran (dirt) sebesar 5-6\%, dan prosentase kernel pecah $\leq 15 \%$. KSB merupakan tangki tempat penyimpanan sementara kernel produksi sebelum adanya pengiriman kernel (despatch kernel). Kapasitas penyimpanan kernel KSB setiap PKS memiliki kapasitas dan jumlah yang berbeda tergantung pada kapasitas olah pabrik.
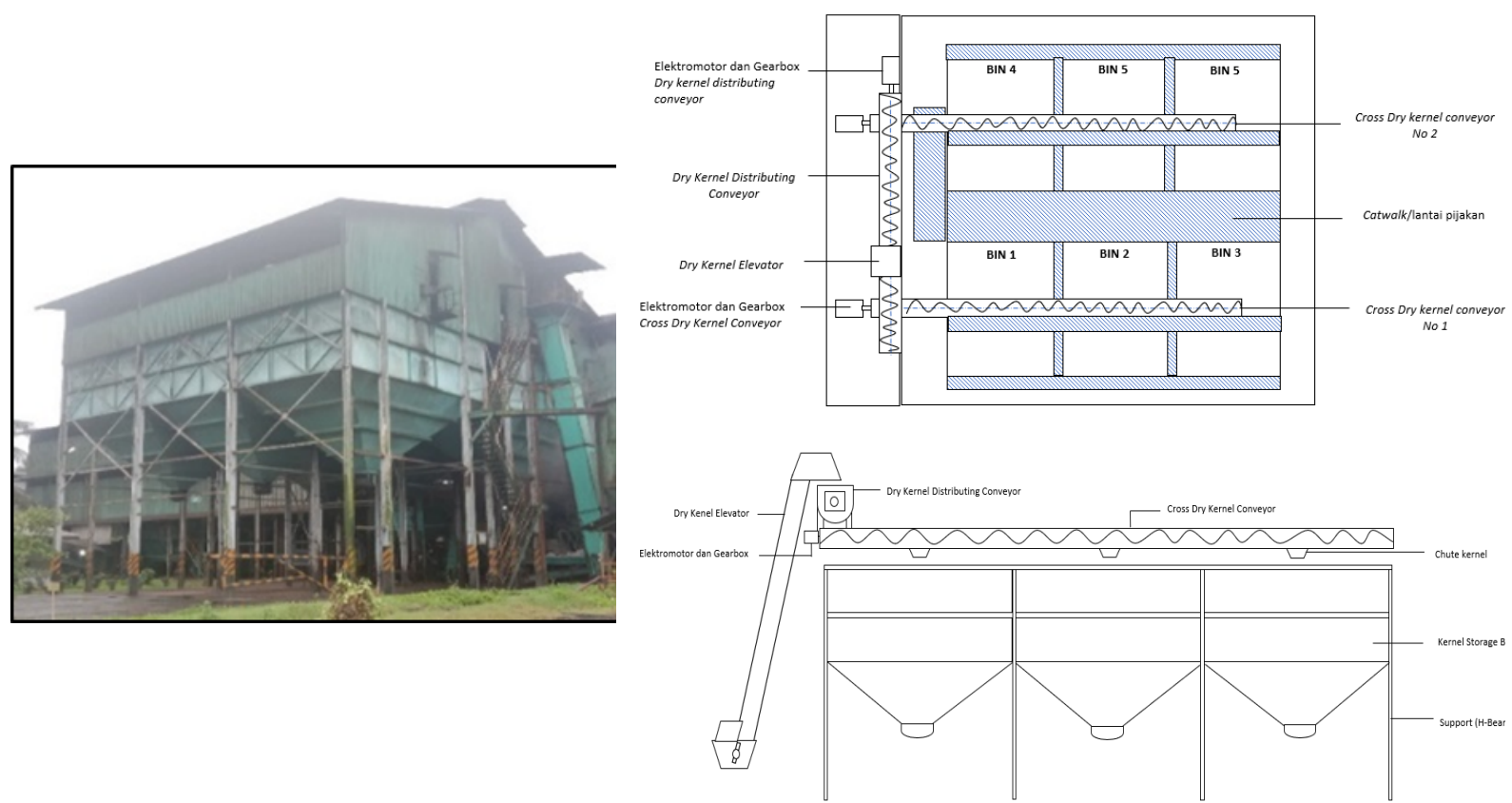

Gambar 2. Foto Stasiun Nut and Kernel (kiri) dan gambar tampak atas dan depan dari KSB (kanan)

(Sumber: dokumen sendiri)

\subsection{Indikator dan Sounding}

Indikator merupakan sesuatu yang memberikan petunjuk atau keterangan. Pengertian indikator adalah sesuatu yang digunakan untuk menentukan berbagai variabel yang dapat membantu penggunanya untuk melakukan pengukuran terhadap perubahan yang terjadi secara langsung/tidak langsung. Fungsi indikator adalah sebagai penanda terjadinya perubahan dan bersifat tetap, serta pedoman untuk menyusun alat ukur, dan memberikan penilaian secara jelas. Dengan menggunakan indikator, perhitungan dan analisis untuk variabel dapat dijawab secara ilmiah karena menggunakan indikator tertentu, sehingga nilai yang didapat dapat diukur secara jelas bukan hanya berdasarkan hipotesis atau teoritis semata.

Sounding merupakan proses pengukuran dan perhitungan terhadap suatu produk (hasil produksi) untuk mengetahui stock/jumlah yang ada. Proses sounding ini diperlakukan kepada CPO dan PK yang merupakan produk hasil dari PKS. Sounding CPO dilakukan untuk mengukur level ketinggian minyak dan temperatur $\mathrm{CPO}$ yang ada dalam tangki timbun (storage tank). Sedangkan sounding PK merupakan pengukuran level kernel di dalam KSB. Alat ukur meteran sounding dihitung berdasarkan tabel volume tangki ukur yang telah dikalibrasi Dinas Perindustrian dan Perdagangan.

\subsection{Peralatan Elektronik dan Rangkaian Kontrol Motor Listrik}

(a) Peralatan Elektronik Limit Switch dan Relay

Limit switch merupakan alat yang berfungsi untuk memutuskan dan 


\section{JVTI}

Research Paper Vol 3, No 2, Tahun 2021

menghubungkan arus listrik pada suatu rangkaian listrik. Limit switch memiliki tiga buah terminal, yaitu: central terminal, normally close (NC) terminal, dan normally open (NO) terminal. Limit switch digunakan untuk membatasi kerja dari suatu alat yang sedang beroperasi. Terminal NC, NO, dan central dapat digunakan untuk memutuskan aliran listrik pada suatu rangkaian atau sebaliknya. Limit switch adalah jenis saklar yang dilengkapi dengan katup yang berfungsi menggantikan tombol. Prinsip kerja limit switch sama seperti saklar Push ON, yaitu hanya akan menghubung pada saat katupnya ditekan pada batas penekanan tertentu yang
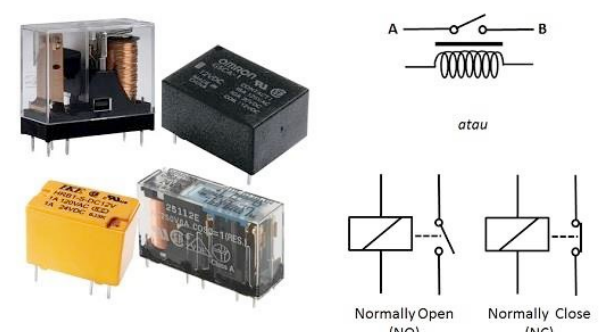

Gambar 3. Peralatan elektronik limit switch (kiri) dan relay (kanan)[2]

(b) Rangkaian Kontrol Motor Listrik Direct On Line (DOL) dan Forward Reverse (FR)

Pengasutan DOL merupakan pengasutan motor listrik 3 fasa dengan metode pemberian tegangan langsung dari sumber tegangan ke motor listrik melalui kontaktor magnetik. Rangkaian kontrol FR digunakan untuk membalik arah putaran motor induksi 3 phasa, yaitu forward (maju/ke arah kanan) dan reverse (mundur/ke arah kiri)[8].

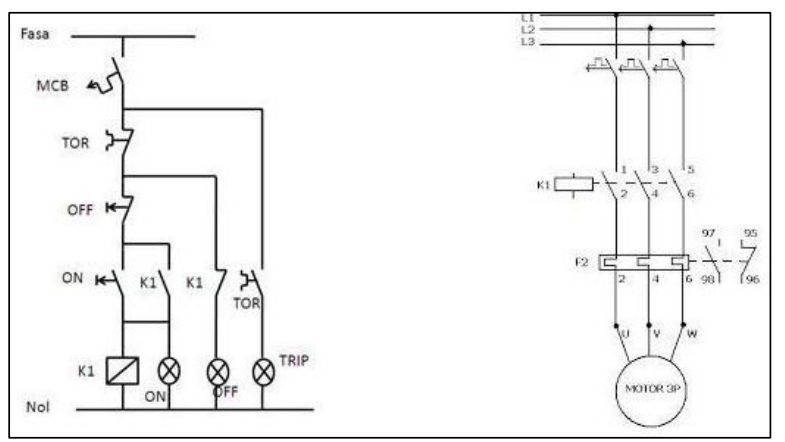

Gambar 4. Rangkaian kontrol pengasutan motor listrik DOL (kiri) dan kontrol motor listrik Forward Reverse (kanan)[8]

\section{Metode Penelitian}

Diagram alir penelitian mengikuti langkah-langkah yang diawali dengan studi pustaka dan studi lapangan secara paralel. Studi pustaka diperlukan untuk mengumpulkan data dan informasi yang diperlukan untuk menunjang pencarian solusi dan teori atas persoalan yang ditemukan saat studi lapangan.

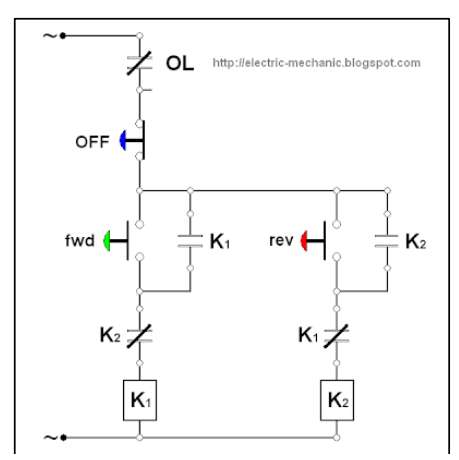

telah ditentukan dan akan memutus saat katup tidak ditekan. Limit switch termasuk dalam kategori sensor mekanis, yaitu sensor yang memberikan perubahan elektrik saat terjadi perubahan mekanik pada sensor tersebut.

Relay adalah saklar (switch) yang dioperasikan secara listrik dan merupakan komponen elektromekanikal yang terdiri dari dua bagian utama, yakni elektromagnet (coil) dan mekanikal (seperangkat kontak saklar/switch). Relay menggunakan prinsip elektromagnetik untuk menggerakkan kontak saklar, sehingga dengan arus listrik yang kecil (low power) dapat menghantarkan listrik yang bertegangan lebih tinggi[2].

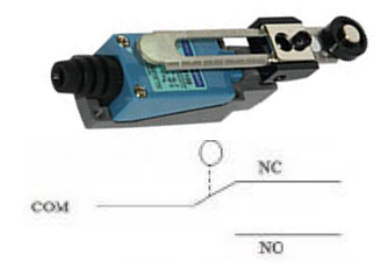

Langkah-langkah penelitian digambrakan dalam diagram alir berikut. 


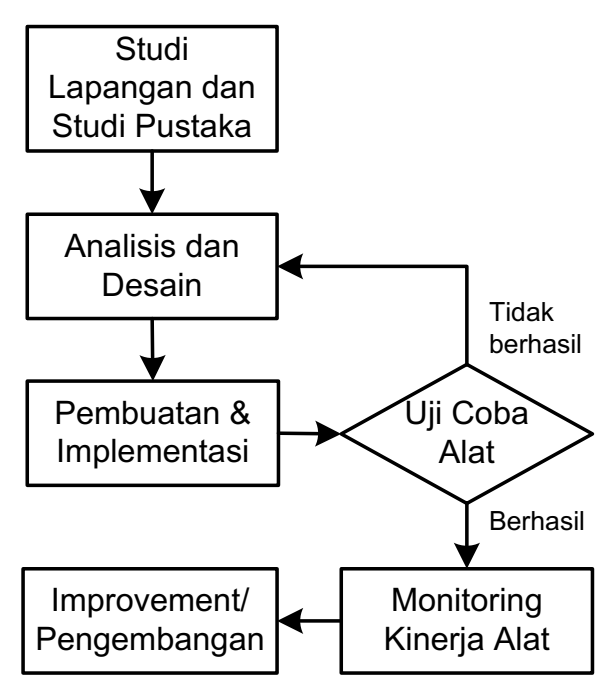

Gambar 5. Diagram alir penelitian

\section{Hasil dan Kajian Penelitian}

\subsection{Identifikasi dan Analisis Akar Penyebab} Masalah

Tahapan mencari akar penyebab (root cause) masalah dilakukan dengan menggunakan alat bantu Diagram Ishikawa. Langkah pertama dalam mencari penyebab masalah adalah dengan melakukan identifikasi serta mengelompokkan ke dalam kategori utama. Empat kategori utama, yaitu aspek Manusia, merupakan bagian SDM yang berperan sebagai operator dalam pengoperasian mesin di Stasiun Nut and Kernel. Operator Stasiun Nut and Kernel berjumlah satu orang per shift. Operator ini bertugas mengoperasikan seluruh peralatan mesin di Stasiun Nut and Kernel sehingga kurang optimal dalam pengontrolan. Selanjutnya aspek Material, dimana keberadaan konveyor Cross Dry Kernel (CDK) berada di atas ketinggian KSB. Aspek ketiga Metode, dikarenakan posisi sarana material ini berada di atas, operator harus naik dan turun tangga untuk mengontrol volume KSB tersebut. Jika operator tidak rutin mengecek, maka berpotensi kernel di KSB penuh dan menumpuk di atas konveyor. Aspek keempat Mesin, teridentifkasi belum adanya alat indikator yang menandakan bahwa kernel di KSB dalam kondisi penuh/rendah. Hal inilah yang menjadi penyebab utama terjadinya penumpukan kernel. Atas dasar hal tersebut, perlu dibuat alat indikator kernel di KSB. Dari pengelompokan tersebut diketahui efek yang terjadi jika salah satu tidak dikontrol adalah kernel penuh dan menumpuk pada konveyor CDK yang bisa berdampak kepada kerusakan alat. Berikut ditunjukkan Diagram Ishikawa proses menemukan akar penyebab masalah.

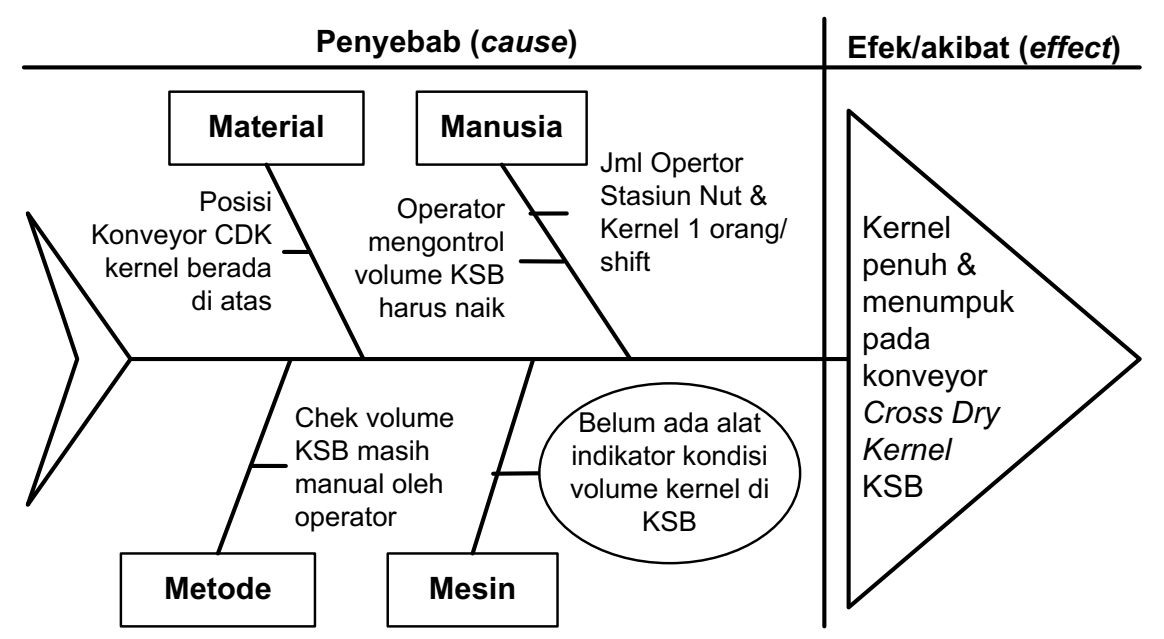

Gambar 6. Diagram Ishikawa dalam analisis akar penyebab

Hasil identifikasi menggunakan Diagram Ishikawa di atas ditampilkan dalam bentuk tabel supaya secara visual lebih mudah untuk dilakukan pengechekan secara terstruktur dengan menggunakan alat bantu $5 \mathrm{~W}+1 \mathrm{H}$.

Tabel 1 Rangkuman Hasil Identifikasi dan Analisis

\begin{tabular}{|c|c|c|c|c|c|}
\hline $\begin{array}{c}\text { What } \\
\text { (Apa) }\end{array}$ & $\begin{array}{c}\text { Why } \\
\text { (Mengapa) }\end{array}$ & $\begin{array}{c}\text { Who } \\
\text { (Siapa) }\end{array}$ & $\begin{array}{c}\text { Where } \\
\text { (Dimana) }\end{array}$ & $\begin{array}{c}\text { When } \\
\text { (Kapan) }\end{array}$ & $\begin{array}{c}\text { How } \\
\text { (Bagaimana) }\end{array}$ \\
\hline
\end{tabular}


Research Paper Vol 3, No 2, Tahun 2021

\begin{tabular}{|c|c|c|c|c|c|}
\hline Kernel & Penumpukan & Operator & Stasiun & Bulan & $\begin{array}{c}\text { Pembuatan alat } \\
\text { penuh }\end{array}$ \\
Kernel secara & Stasiun Nut and & Nut and & Maret s/d & indikator volume \\
kernel di KSB
\end{tabular}

4.2 Pembuatan Rangkaian Kontrol Indikator KSB

Rancangan rangkaian kontrol indikator KSB dibuat dan disimulasikan pada software Fluidsim.
Berikut disajikan gambar rangkaian kontrol yang dirancang tersebut.

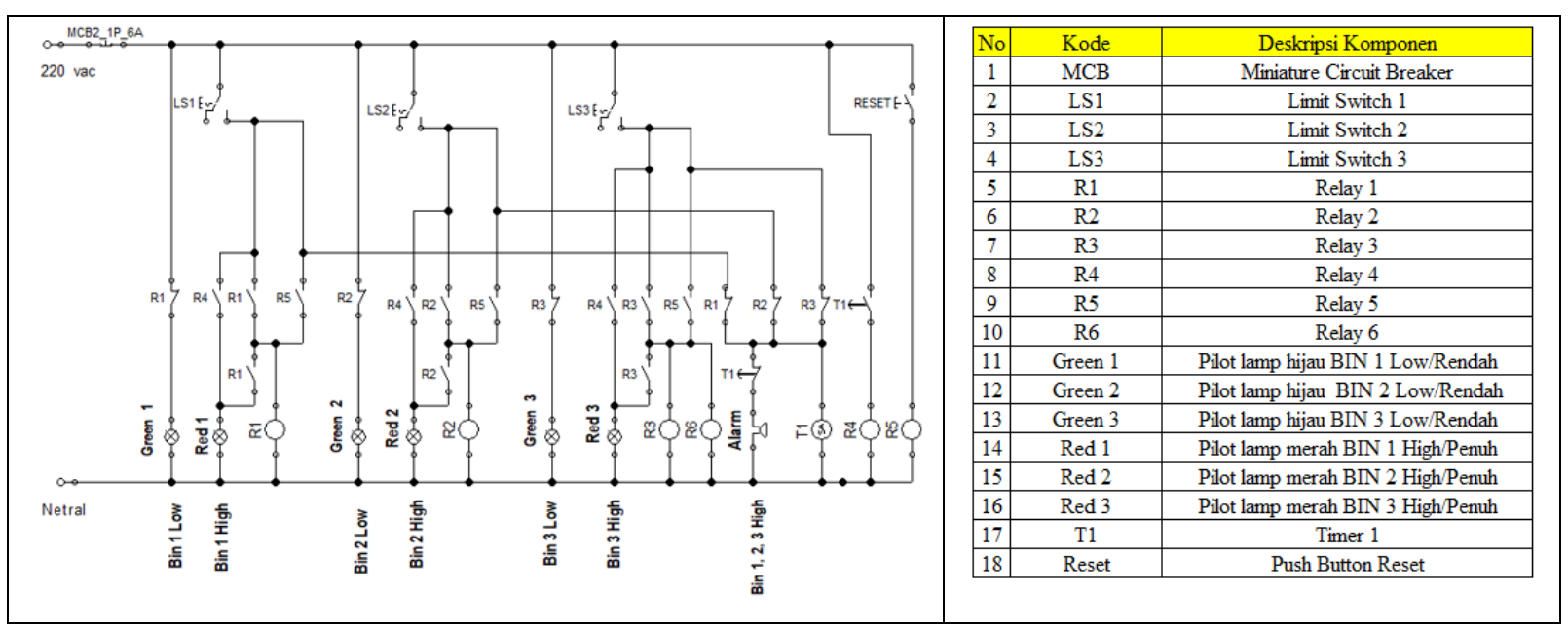

Gambar 7. Rangkaian kontrol indikator KSB

\subsection{Perancangan dan Pembuatan Alat Indikator Volume Kernel di KSB}

Pembuatan rangkaian kontrol putaran Reverse motor listrik pada konveyor Dry Kernel Distributing. Spesifikasi motor listrik merek TECO dengan daya dan putaran $4 \mathrm{~kW} / 5,5$ HP $1440 \mathrm{rpm}$ dengan tegangan 380 415 Volt dan arus 8.74-8.00 Ampere.
Spesifikasi gearbox merek Brook Hansen tipe SFN 34B dengan reduksi putaran $60 \mathrm{rpm}$. Gambar rancangan rangkaian starter motor listrik yang digunakan, yaitu pengasutan langsung atau Direct On Line (DOL). Adapun rangkaian kontrol otomatis forward \& reverse dan on/off konveyor Dry Kernel Distributing ditunjukkan pada gambar berikut. 
Research Paper Vol 3, No 2, Tahun 2021

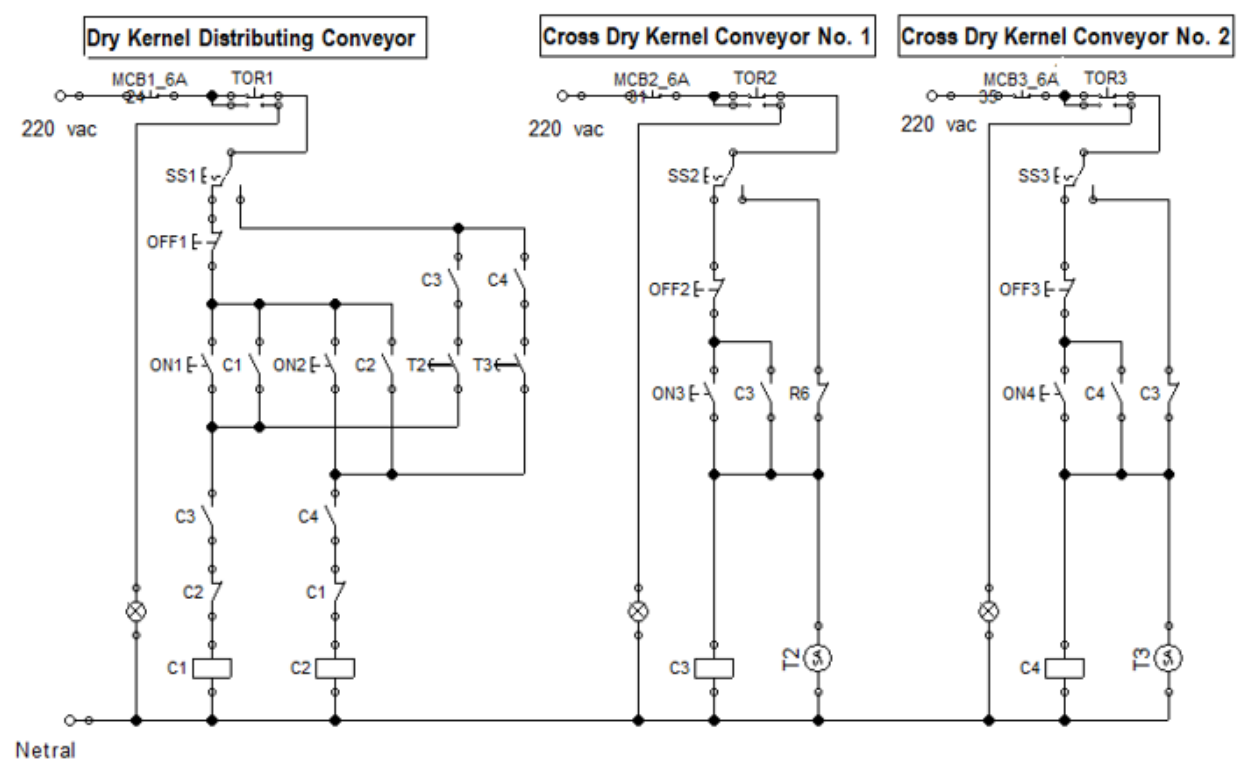

Gambar 8. Rancangan rangkaian kontrol manual/otomatis putaran motor forward \& reverse

Hasil pembuatan alat indikator KSB setelah dilakukan perakitan dan pemasangan disajikan

pada gambar berikut.

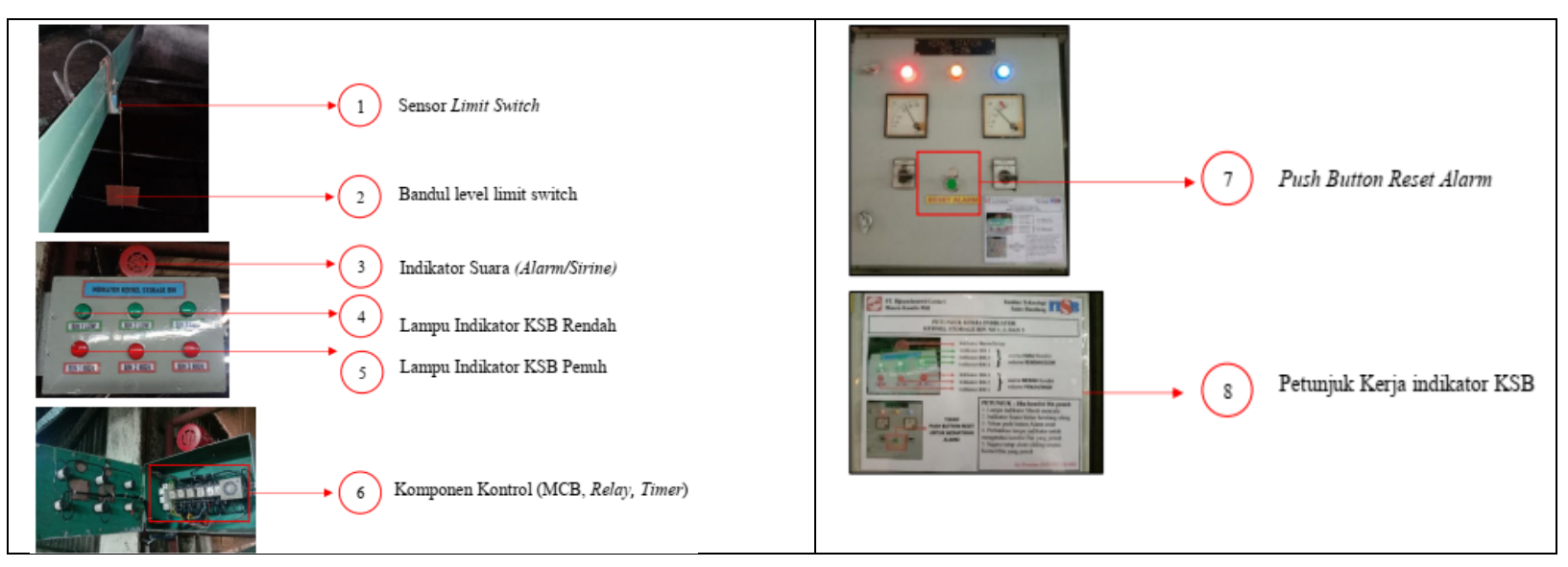

Gambar 9. Rangkaian kontrol manual/otomatis putaran motor Forward \& Reverse

Adapun jenis/tipe dan fungsi masing-masing komponen pada alat indikator KSB yang telah dibuat disajikan pada tabel berikut beserta tata letak pemasangan alat di Stasiun Nut and Kernel.

Tabel 2. Jenis/tipe dan fungsi masing-masing komponen alat indikator KSB

\begin{tabular}{|l|l|l|}
\hline \multicolumn{1}{|c|}{ Nama } & \multicolumn{1}{c|}{ Jenis/Tipe } & \multicolumn{1}{c|}{ Fungsi } \\
\hline $\begin{array}{l}\text { Sensor } \text { Limit } \\
\text { Switch }\end{array}$ & Sensor mekanik & $\begin{array}{l}\text { mendeteksi perubahan gerakan mekanik dan mengirim sinyal listrik ke } \\
\text { panel indikator KSB }\end{array}$ \\
\hline $\begin{array}{l}\text { Level } \text { Limit } \\
\text { switch }\end{array}$ & Bandul & memberikan gerakan mekanik ketika terdeteksi kernel penuh \\
\hline Indikator Audio & $\begin{array}{l}\text { Mini Sirine MS- } \\
190220 \text { VAC }\end{array}$ & memberikan indikator suara ketika KSB penuh. \\
\hline Indikator Visual & $\begin{array}{l}\text { Pilot lamp 220 } \\
\text { VAC }\end{array}$ & $\begin{array}{l}\text { penunjuk volume tanki KSB penuh/rendah. Warna hijau menunjukkan } \\
\text { volume KSB rendah dan dan merah menunjukkan volume KSB penuh }\end{array}$ \\
\hline Kontrol & MCB, Relay, & mengatur sistem kerja indikator \\
\hline
\end{tabular}


Research Paper Vol 3, No 2, Tahun 2021

\begin{tabular}{|l|l|l|}
\hline \multicolumn{1}{|c|}{ Nama } & \multicolumn{1}{|c|}{ Jenis/Tipe } & \multicolumn{1}{c|}{ Fungsi } \\
\hline & Timer & \multicolumn{1}{c|}{} \\
\hline Reset Alarm & Push Button & mengembalikan kinerja alat indikator (merestart) \\
\hline $\begin{array}{l}\text { Petunjuk kerja } \\
\text { indikator KSB }\end{array}$ & Poster & $\begin{array}{l}\text { panduan operator Stasiun Nut and Kernel maupun orang lain dalam } \\
\text { pengoperasian alat indikator KSB. }\end{array}$ \\
\hline
\end{tabular}

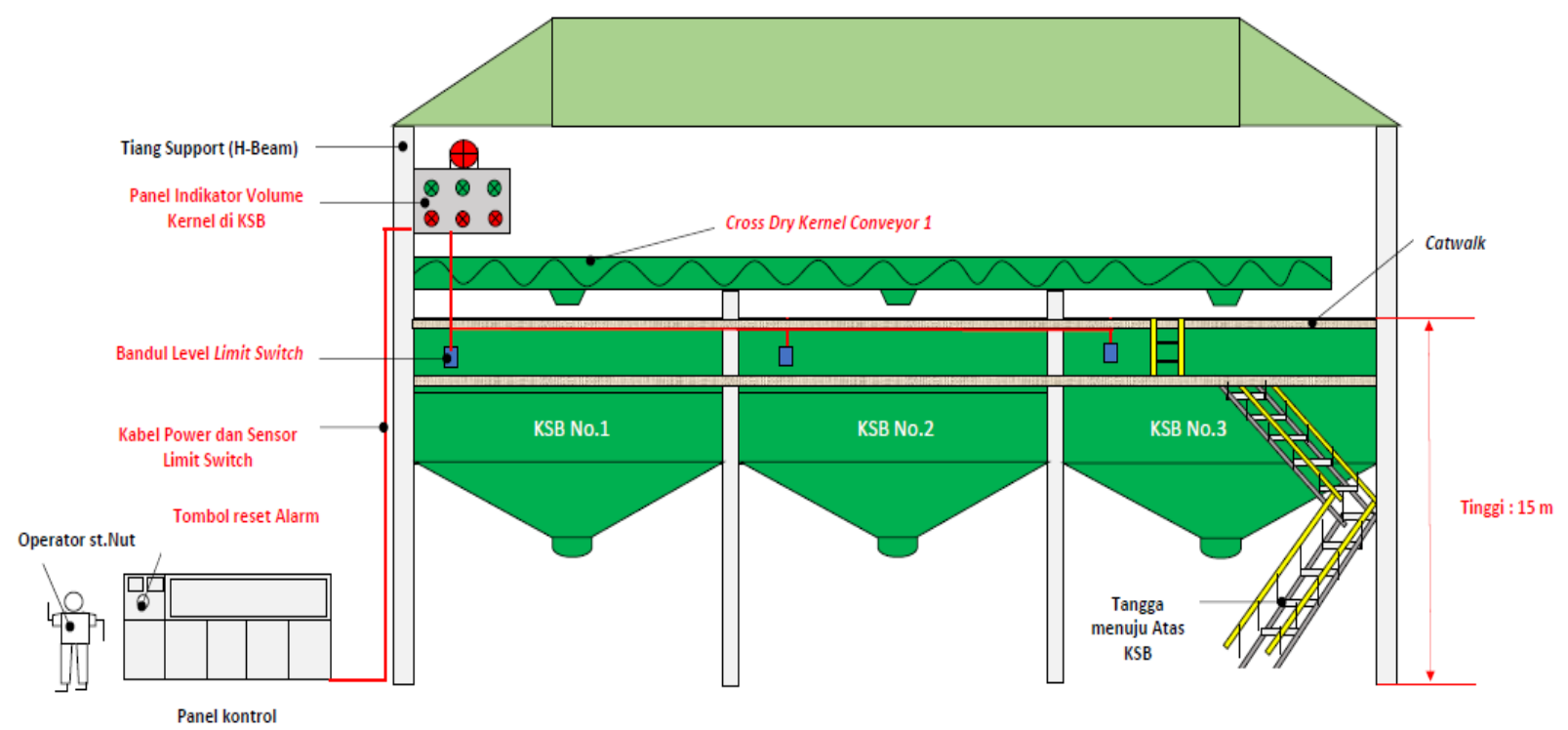

Gambar 10. Tata letak pemasangan alat indikator KSB

\subsection{Data Hasil Pengujian Alat Indikator}

Alat indikator yang dirancang perlu dilakukan pengujian terhadap kinerja dari sistem tersebut dengan tujuan apakah kinerja dari sistem tersebut sudah berfungsi dengan baik. Pegujian mencakup kinerja indikator lampu, suara/alarm, dan rangkaian kontrol.

\section{(a)Pengujian Lampu dan Alarm}

Indikator lampu yang digunakan adalah tipe pilot lamp 220 VAC. Indikasi warna lampu indikator ditunjukkan oleh 2 (dua) warna, yaitu hijau menunjukkan volume KSB dalam kondisi rendah/low dan merah menunjukkan volume KSB dalam kondisi penuh/high. Selain itu, alat indikator dilengkapi dengan indikator suara (alarm/sirine) sebagai peringatan dini. Indikator suara yang digunakan jenis Mini Sirine MS-190. Penggunaan indikator suara ini dimaksudkan untuk memberitahukan kepada operator bahwa kondisi KSB penuh.

\section{(b)Data Hasil Sounding KSB}

Data sounding merupakan data pengukuran volume kernel di KSB menggunakan alat ukur meteran sounding kernel. Pengambilan data sounding kernel KSB dilakukan selama 3 (tiga) bulan, yaitu April, Mei dan Juni 2021. Data sounding diambil pada KSB No. 1, 2 dan 3 dengan tujuan untuk mengetahui produksi kernel ketika volume KSB penuh, serta indikator lampu dan suara sirine menyala (bekerja), hasil pengukuran ditunjukkan dalam Tabel 3.

Berdasarkan data pada Tabel 3, diperoleh nilai rata-rata indikator KSB bekerja, yaitu:

(a)KSB 1 pada pengukuran meteran sounding $187 \mathrm{~cm}$ dan tonase kernel 85,49 Ton;

(b)KSB 2 pada pengukuran meteran sounding $172 \mathrm{~cm}$ dan tonase kernel 90,89 Ton; dan

(c)KSB 3 pada pengukuran meteran sounding $215 \mathrm{~cm}$ dan tonase kernel 62,75 Ton.

Tabel 3. Data Sounding KSB bulan April (a), Mei (b) dan Juni (c) 2021 


\section{JVTI}

JURNAL VOKASI

TEKNOLOGI INDUSTRI
e-ISSN 2686-3545

p-ISSN 2656-6664

\section{Research Paper Vol 3, No 2, Tahun 2021}

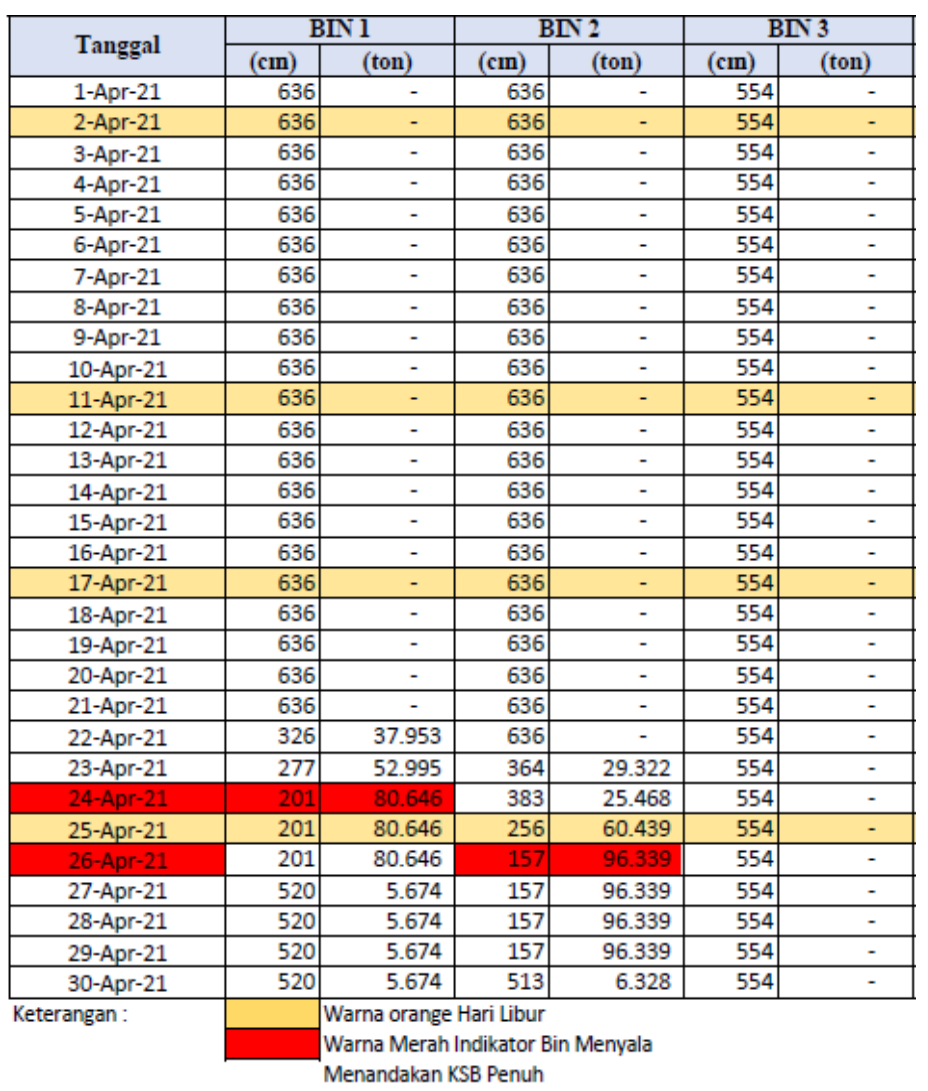

\begin{tabular}{|c|c|c|c|c|c|c|}
\hline \multirow{2}{*}{ Tanggal } & \multicolumn{2}{|c|}{ BIN I } & \multicolumn{2}{|c|}{ BN 2 } & \multicolumn{2}{|c|}{ BN3 3} \\
\hline & (cm) & (ton) & (cm) & (ton) & (cm) & (ton) \\
\hline \multicolumn{7}{|l|}{01 Mei 2021} \\
\hline 02 Mei 2021 & 520 & 5.674 & 513 & 6.328 & 554 & - \\
\hline 03 Mei 2021 & 520 & 5.674 & 513 & 6.328 & 554 & - \\
\hline 04 Mei 2021 & 520 & 5.674 & 513 & 6.328 & 554 & - \\
\hline 05 Mei 2021 & 520 & 5.674 & 513 & 6.328 & 554 & - \\
\hline 06 Mei 2021 & 520 & 5.674 & 482 & 9.744 & 554 & - \\
\hline 07 Mei 2021 & 520 & 5.674 & 482 & 9.744 & 554 & - \\
\hline 08 Mei 2021 & 363 & 29.626 & 482 & 9.744 & 554 & - \\
\hline 09 Mei 2021 & 363 & 29.626 & 482 & 9.744 & 554 & - \\
\hline 10 Mei 2021 & 221 & 73.369 & 482 & 9.744 & 554 & - \\
\hline 11 Mei 2021 & 221 & 73.369 & 482 & 9.744 & 329 & 25.71 \\
\hline 12 Mei 2021 & 221 & 73.369 & 482 & 9.744 & 329 & 25.71 \\
\hline 13 Mei 2021 & 221 & 73.369 & 482 & 9.744 & 329 & 25.71 \\
\hline 14 Mei 2021 & 221 & 73.369 & 482 & 9.744 & 329 & 25.71 \\
\hline 15 Mei 2021 & 221 & 73.369 & 482 & 9.744 & 329 & 25.71 \\
\hline 16 Mei 2021 & 221 & 73.369 & 482 & 9.744 & 329 & 25.71 \\
\hline 17 Mei 2021 & 221 & 73.369 & 482 & 9.744 & 329 & 25.71 \\
\hline 18 Mei 2021 & 221 & 73.369 & 482 & 9.744 & 329 & 25.71 \\
\hline 19 Mei 2021 & 221 & 73.369 & 482 & 9.744 & 329 & 25.71 \\
\hline 20 Mei 2021 & 580 & 1.433 & 482 & 9.744 & 329 & 25.71 \\
\hline 21 Mei 2021 & 238 & 67.184 & 337 & 35.258 & 554 & - \\
\hline 22 Mei 2021 & 191 & 84.284 & 281 & 51.374 & 554 & - \\
\hline 23 Mei 2021 & 215 & 75.552 & 261 & 58.626 & 554 & - \\
\hline 24 Mei 2021 & 215 & 75.552 & 184 & 86.548 & 554 & - \\
\hline 25 Mei 2021 & 205 & 79.191 & 197 & 81.834 & 406 & 11.40 \\
\hline 26 Mei 2021 & 205 & 79.191 & 197 & 81.834 & 406 & 11.40 \\
\hline 27 Mei 2021 & 205 & 79.191 & 197 & 81.834 & 406 & 11.40 \\
\hline 28 Mei 2021 & 205 & 79.191 & 197 & 81.834 & 285 & 37.16 \\
\hline 29 Mei 2021 & 205 & 79.191 & 197 & 81.834 & 285 & 37.16 \\
\hline 30 Mei 2021 & 137 & 103.932 & 171 & 91.262 & 244 & 52.15 \\
\hline 31 Mei 2021 & 137 & 103.932 & 475 & 10.615 & 272 & 41.91 \\
\hline \multirow[t]{3}{*}{ Keterangan: } & & \multicolumn{5}{|c|}{ Warna orange Hari Libur } \\
\hline & & \multirow{2}{*}{\multicolumn{5}{|c|}{$\begin{array}{l}\text { Warna Merah Indikator Bin Menyala } \\
\text { Menandakan KSB Penuh }\end{array}$}} \\
\hline & & & & & & \\
\hline
\end{tabular}


Research Paper Vol 3, No 2, Tahun 2021

\begin{tabular}{|c|r|r|r|r|r|r|}
\hline \multirow{2}{*}{ Tanggal } & \multicolumn{2}{|c|}{ BIN 1 } & \multicolumn{2}{c|}{ BIN 2 } & \multicolumn{2}{|c|}{ BIN 3 } \\
\cline { 2 - 7 } & (cm) & \multicolumn{1}{c|}{ (ton) } & \multicolumn{1}{c|}{ (cm) } & \multicolumn{1}{c|}{ (ton) } & \multicolumn{1}{c|}{ (cm) } & (ton) \\
\hline 1 Juni 2021 & 137 & 103.932 & 475 & 10.615 & 272 & 41.91 \\
\hline 2 Juni 2021 & 137 & 103.932 & 157 & 96.339 & 230 & 57.27 \\
\hline 3 Juni 2021 & 137 & 103.932 & 157 & 96.339 & 199 & 68.61 \\
\hline 4 Juni 2021 & 137 & 103.932 & 339 & 34.800 & 199 & 68.61 \\
\hline 5 Juni 2021 & 137 & 103.932 & 299 & 44.846 & 437 & 7.24 \\
\hline 6 Juni 2021 & 137 & 103.932 & 196 & 82.196 & 437 & 7.24 \\
\hline 7 Juni 2021 & 137 & 103.932 & 281 & 51.374 & 277 & 40.09 \\
\hline 8 Juni 2021 & 530 & 4.777 & 191 & 84.010 & 277 & 40.09 \\
\hline 9 Juni 2021 & 317 & 40.132 & 191 & 84.010 & 202 & 67.51 \\
\hline 10 Juni 2021 & 257 & 60.271 & 549 & 3.271 & 447 & 6.10 \\
\hline 11 Juni 2021 & 210 & 77.372 & 549 & 3.271 & 510 & 1.13 \\
\hline 12 Juni 2021 & 194 & 83.193 & 549 & 3.271 & 510 & 1.13 \\
\hline 13 Juni 2021 & 194 & 83.193 & 549 & 3.271 & 510 & 1.13 \\
\hline 14 Juni 2021 & 551 & 3.140 & 269 & 55.725 & 510 & 1.13 \\
\hline 15 Juni 2021 & 551 & 3.140 & 416 & 19.414 & 554 & - \\
\hline 16 Juni 2021 & 551 & 3.140 & 416 & 19.414 & 554 & - \\
\hline 17 Juni 2021 & 551 & 3.140 & 416 & 19.414 & 554 & - \\
\hline 18 Juni 2021 & 551 & 3.140 & 416 & 19.414 & 554 & - \\
\hline 19 Juni 2021 & 240 & 66.457 & 636 & - & 554 & - \\
\hline 20 Juni 2021 & 240 & 66.457 & 416 & 19.414 & 554 & - \\
\hline 21 Juni 2021 & 320 & 39.399 & 636 & - & 554 & - \\
\hline 22 Juni 2021 & 217 & 74.825 & 636 & - & 554 & - \\
\hline 23 Juni 2021 & 217 & 74.825 & 636 & - & 554 & - \\
\hline 24 Juni 2021 & 182 & 87.559 & 636 & - & 554 & - \\
\hline 25 Juni 2021 & 289 & 48.629 & 636 & - & 554 & - \\
\hline 26 Juni 2021 & 440 & 15.570 & 636 & - & 554 & - \\
\hline 27 Juni 2021 & 636 & - & 636 & - & 554 & - \\
\hline 28 Juni 2021 & 636 & - & 636 & - & 554 & - \\
\hline 29 Juni 2021 & 636 & - & 636 & - & 554 & - \\
\hline 30 Juni 2021 & 636 & - & 636 & - & 554 & - \\
\hline Keterangan: & & Warna orange Hari Libur & & & \\
\cline { 2 - 7 } & & Warna Merah Indikator Bin Menyala & & \\
\hline & & Menandakan KSB Penuh & & & \\
\hline Rangkaian & utaran & & & & \\
\hline
\end{tabular}

(c)Pengujian Rangkaian Putaran Reverse Motor Listrik Konveyor Dry Kernel Distributing

Pengoperasian manual konveyor berfungsi dengan baik dan penyimpanan kernel masuk ke KSB No. 1, 2 dan 3. Pengambilan data percobaan dilakukan dengan kontrol otomatis, yaitu mengatur Switch selector ke arah automatic. Hasil pengujian konveyor cross dry kernel No. 1 dan dry kernel distributing conveyor secara otomatis beroperasi yang menunjukkan konveyor berfungsi dengan baik. Saat penyimpanan kernel di KSB No. 1, 2 dan 3 dalam keadaan penuh, motor listrik konveyor cross dry kernel No. 1 otomatis $O F F$ dan konveyor cross dry kernel No. 2 otomatis $O N$, serta putaran motor listrik konveyor dry kernel distributing otomatis berubah putaran dariforward menjadi reverse. Perubahan putaran motor ini memberikan efek penyimpanan kernel ke KSB No. 4, 5 dan 6. Pengujian memberikan hasil bahwa rangkaian kontrol putaran otomatis reverse motor listrik konveyor dry kernel distributing telah bekerja dengan baik. Sistem otomatis memudahkan operator mengontrol proses penyimpanan kernel di KSB, sehingga dapat meminimalkan terjadinya penumpukan kernel di KSB No. 3.

\section{Kesimpulan dan Saran}

Diperoleh kesimpulan bahwa kinerja alat indikator volume kernel di KSB yang dirancang dan dibuat berfungsi dengan baik. Hal ini ditunjukkan dengan tidak terjadi lagi penumpukan kernel dan tidak terdapat kerusakan pada konveyor, serta memberikan kemudahan kepada operator dalam mengontrol penyimpanan kernel produksi di KSB. Kinerja rangkaian putaran reverse pada motor listrik 3 fasa konveyor dry kernel distributing yang dibuat bekerja dengan baik, motor listrik secara otomatis berpindah putaran dari forward menjadi reverse ketika volume tangki KSB yang diisi penuh, serta konveyor dry cross kernel otomatis mengisi kernel produksi ke KSB yang belum terisi.

Saran untuk pengembangan kedepan, alat indikator di KSB ini dapat ditambahkan aktuator yang terhubung dengan konveyor chute dry cross kernel, sehingga buka/tutup chute conveyor dapat bekerja secara otomatis. 


\section{DAFTAR PUSTAKA}

[1] Andasuryani dan M.Makky. 2021. Kontrol Otomatik. Mata Kuliah Kontrol Otomatik. Universitas Andalas

[2] Muhammad Saleh, Munnik Haryanti. 2017. Rancang Bangun Sistem Keamanan Rumah Menggunakan Relay. ISSN: 2086-9479. Jurnal Teknologi Elektro (JTE), Universitas Mercu Buana. DOI: http://dx.doi.org/10.22441/jte.v8i2.1601

[3] Wahyu Zainal Riyadi. 2018. Pengujian MCB Berdasarkan Standar IEC 947-2. Yogyakarta. Jurusan Teknik Elektro. Universitas Islam Indonesia. https://dspace.uii.ac.id/handle/123456789/6 216

[4]I Gede Siden Sudaryana. 2015. Pemanfaatan Relai Tunda Waktu dan Kontaktor pada Panel Hubung Bagi (PHB) untuk Praktek Pengasutan Starting Motor Star Delta. ISSN 0216-3241. Teknik Elektro Fakultas Teknik dan Kejuruan. Vol. 12, No. 2, Juli 2015 : 131-142. DOI: http://dx.doi.org/10.23887/jptkundiksha.v12i2.6478

[5] Hendril Satriyan Purnama. 2014. Makalah Motor listrik. Teknik Elektro. Universitas Ahmad Dahlan. Yogyakarta

[6]Fishbone Diagram (Ishikawa Diagram) dalam

(https://www.weha.web.id/2010/05/fishbon e-diagram-ishikawa-diagram.html) diakses tanggal 1 Juni 2021

[7] Muhammad Robith. 2015. Pinsip Kerja Motor Induksi 3 Fasa dalam (https://www.insinyoer.com/prinsip-kerjamotor-induksi-3-fasa/) diakses tanggal 26 Mei 2021

[8] Teguh Giantoro. 2018. Rangkaian DOL (Direct On Line) Starter Motor 3 Phasa, Wiring Diagram dan penjelasan lengkap dalam

(https://teguhgiantoro.wordpress.com/2018/ 08/16/rangkaian-dol-direct-on-line-startermotor-3-ph-wiring-diagram-danpenjelasan-lengkap/) diakses tanggal 26 Mei 2021 